Studi Kasus

\title{
Penurunan Nyeri dengan Intervensi Kombinasi Terapi Relaksasi Pernafasan dan Terapi SEFT pada Pasien dengan Kanker Servik Stadium IIIB
}

\section{Amalia Warnandiah Safitri ${ }^{1}$, Machmudah Machmudah ${ }^{2}$}

1 Program Studi Pendidikan Profesi Ners, Fakultas Ilmu Keperawatan dan Kesehatan, Universitas Muhammadiyah Semarang

2 Program Studi Keperawatan, Fakultas Ilmu Keperawatan dan Kesehatan, Universitas Muhammadiyah Semarang

\section{Informasi Artikel}

Riwayat Artikel:

- Submit: 5 September 2020

- Diterima: 10 Desember 2020

- Terbit: 11 Januari 2021

Kata kunci:

Kanker servik; Nyeri;

Relaksasi; Terapi SEFT

\section{PENDAHULUAN}

Kanker servik merupakan kanker primer servik (porsio dan kanalis servikalis) yang ditimbulkan karena adanya infeksi Human Papilloma Virus (HPV) (Aziyah, 2017). Wanita yang terkena kanker servik bisa

\section{Abstrak}

Kanker servik merupakan kanker primer karena adanya infeksi Human Papilloma Virus (HPV). Nyeri pada pasien kanker servik stadium lanjut merupakan nyeri kronis yang bersifat subjektif. Terapi SEFT merupakan suatu teknik penggabungan dari sistem energi tubuh (energy medicine) dan terapi spiritualitas dengan menggunakan metode tapping (ketukan) pada tubuh. Sebelum dilakukan terapi SEFT pasien dirilekskan dengan metode relaksasi nafas dalam 3 kali tarikan nafas setelah itu lakukan terapi SEFT 1 kali setiap pertemuan dengan kisaran waktu 15 menit selama 3 hari dengan pertemuan tidak terstruktur mengikuti pola pada responden. Responden pada penerapan ini yaitu pasien kanker servik stadium IIIB. Hasil menunjukkan adanya penurunan skala nyeri dari skala sedang menjadi ringan pada pasien kanker servik stadium IIIB dengan intervensi terapi relaksasi nafas dalam dan terapi SEFT. Analisis kasus 1 hari pertama skala nyeri 4, sampai di hari ke ketiga skala nyeri mengalami penurunan menjadi 3, untuk kasus 2 hari pertama skala nyeri 3, sampai hari ke ketiga mengalami penurunan menjadi 2. Hasil studi kasus ini menunjukkan bahwa relaksasi nafas dalam dan terapi SEFT mampu menurunkan skala nyeri. Pada kasus kali ini peneliti menggunakan dua responden pasien penderita kanker servik dengan stadium IIIB. Spiritual Emosional Freedom Technique (SEFT) bekerja dengan prinsip yang kurang lebih sama dengan akupuntur \& akupressur. Teknik ini berusaha merangsang titik-titik kunci di sepanjang 12 jalur energi (energi meridian) tubuh yang sangat berpengaruh pada kesehatan kita. Terapi nonfarmakologi relaksasi pernafasan dan terapi SEFT mampu menurunkan skala nyeri pada pasien kanker servik.

Corresponding author:

Amalia Warnandiah Safitri

warnandiah@gmail.com

Holistic Nursing Care Approach, Vol 1 No 1, Januari 2021

e-ISSN: 2808-2095

DOI: https://doi.org/10.26714/hnca.v1i1.8252

menjadikan masalah holistic yang disebabkan dari penyakit itu sendiri ataupun pengobatan, seperti ketidakmampuan fisik, masalah nyeri, gangguan mental serta berpengaruh terhadap pekerjaan, sosial dan pengasuhan anak (Susanti, 2017). Data Penderita kanker 
Amalia Warnandiah Safitri - Penurunan Nyeri dengan Intervensi Kombinasi Terapi Relaksasi Pernafasan dan Terapi SEFT pada Pasien dengan Kanker Servik Stadium IIIB

servik di Negara Indonesia mencapai titik yang cukup banyak, data depkes menyatakan bahwa penderita kanker servik mencapai 90- 100 diantara 100.000 penduduknya setiap tahun. Data ini menunjukan bahwa penyakit kanker servik menempati peringkat pertama dari kasus kanker yang menyerang kaum wanita di Indonesia.

Kanker servik di negara Indonesia mulai muncul dari usia perempuan 20 tahun dan dipuncaknya pada usia 50 tahun. Data dari Kementrian Pemberdayaan Perempuan dan Perlindungan Anak terdapat 40-50 kasus temuan baru dengan kasus meninggal hingga 20-25 perempuan yang diakibatkan dari penyakit kanker servik. Kasus tertinggi wanita tertinggi dengan usia 40-64 tahun, kasus meninggal terbanyak di usia 45-64 tahun ada 39 orang (Meihartati, 2017).

Gerakan pencegahan dan deteksi dini kanker pada perempuan Indonesia yang mencakup 11 Provinsi di Indonesia termasuk Provinsi Jawa tengah merupakan Provinsi terbesar yang menyandang penyakit kanker servik setelah provinsi di Jogjakarta. Kota Semarang merupakan Ibu kota Provinsi Jawa Tengah. Penderita kanker servik ditahun 2015-2017 terus mengalami kenaikan, hal ini terbukti bahwa kota semarang banyak penyandang kanker servik pada tahun 2015-2017 dengan total pasien 310 kasus pada tahun 2015, 361 kasus pada tahun 2016 dan 365 kasus pada tahun 2017 (Sihanari, 2018).

Nyeri adalah suatu gejala kanker yang sangat sering menjadi beban berat bagi pasien selama sakit. Nyeri adalah pengaruh aspek dari kualitas hidup penderita kanker servik. Nyeri pasien kanker servik stadium lanjut masuk dalam nyeri kronis dengan nyeri yang bisa dirasakan terus menerus dengan jangka waktu kurang lebih sampai enam bulan bahkan lebih. Pasien yang mengalami nyeri kronis akan berpengaruh terhadap aktivitas kesehariannya seperti makandan tidur, apabila terjadi kurang dukurang keluarga pasien yang mengalami nyeri juga akan mengalami frustasi (Natosba, 2019).Nyeri yang dirasakan pada penderita kanker servik dirasakan dari panggul atau ekstremitas bawah di daerah lumbal dirasa semakin progresif apabila pasien sudah mengalami stadium lanjut (Rahmania, 2017).

Intervensi yang cocok untuk mengurangi ketidaknyamanan dan merilekskan tubuh dari rasa nyeri pada ppasien kanker servik stadium III B yaitu intervensi nyeri non farmakologi salah satunya dengan menggunakan teknik relaksasi. Teknik relaksasi membantu mengembangkan otot, sehingga menurunkan intensitas nyeri atau meningkatkan toleransi nyeri karena dapat mengubah persepsi kognitif dan motivasi efektif pasien. Teknik relaksasi membuat pasien dapat menontrol diri ketika rasa tidak nyaman atau nyeri, stress fisik dan emosi pada nyeri ( Potter 2016).

Teknik relaksasi dengan pernafasan dapat mengendalikan nyeri dengan meminimalkan aktifitas simpatik dalam system saraf otonom. Caranya yaitu perawat mengajarkan pada pasien bagaimana melakukan nafas dalam, nafas lambat (menahan inspirasi secara maksimal) dan bagaimana menghembuskan nafas secara perlahan. Selain untuk menurunkan intensitas nyeri teknik ini juga dapat meningkatkan ventilasi paru dan oksigenasi darah ( Ayu, 2019).

Terapi komplementer merupakan pengobatan yang bisa digunakan untuk penderita kanker servik yang ditimbulkan dari keselarasan tubuh serta pikiran yang diyakini bisa menjadi fasilitas bagi penyembuhan fisik dan psikologis.Terapi komplementer yang bisa digunakan salah satunya yaitu terapi spiritual emosional freedom technique ( SEFT) yang bisa digabungkan dengan latihan nafas dalam. Terapi ( SEFT) termasuk dalam hypnoterapi yang termasuk kedalam penatalaksanaan 
Amalia Warnandiah Safitri - Penurunan Nyeri dengan Intervensi Kombinasi Terapi Relaksasi Pernafasan dan Terapi SEFT pada Pasien dengan Kanker Servik Stadium IIIB

non farmakologi nyeri pada pasien kanker servik. Pengaruh yang dirasakan pada pasien kanker servik saat diberikanterapi hypnosis dan self- hypnosis yaitu lebih bisa menahan rasa sakit dan rasa nyaman (Natosba, 2019).

Terapi SEFT adalah teknik penggabungan system energy tubuh (energy medicine) dan spiritual dengan tapping atau ketukan yang dituju dengan beberapa titik dibagian tubuh tertentu. Terapi SEFT mempunyai banyak manfaat yaitu dapat membantu mengatasi masalah fisik dan emosi (Brahmantia, 2018).

Ketukan (tapping) pada terapi SEFT bisa merangsang serabut pada saraf A- beta, yang diteruskan ke bagian nucleus kolumna dorsalis serta impuls saraf yang dapat diteruskan ke lemnikus melewati jalur kolateral yang terhubung dengan periaqueductal grey area (PAG). Perangsangan PAG dapat menghasilkan enkepalin, berupa opium ditubuh sehingga dapat menurunkan nyeri. Terapi SEFT hampir memiliki kesamaan dengan akupresur namun tetap memiliki perbedaan yaitu terapi SEFT dapat dilakukan dengan mudah, cepat dan sederhana serta tidak menimbulkan resiko karena dilakukan tidak dengan menggunakan jarum atau alat yang lainnya. Terapi SEFT ini melibatkan Tuhan sehingga masalah yang diatasi lebih luas terutama masalah emosi dan fisik (Brahmantia, 2018).

Pengelolaan nyeri pada pasien kanker servik dapat dilakukan dengan memberikan terapi farmakologi maupun non farmakologi. Terapi farmakologi dapat menimbulkan efek samping yang merugikan bagi penderita kanker servik, sehingga perlu dikembangkan intervensi pengelolaan nyeri secara non farmakologi dengan pendekatan komplementer yang terbaik adalah mengontrol nyeri nonfarmakologis pada saat pertama, salah satunya adalah dengan memberikan pesan dengan teknik menggabungkan latihan nafas dalam dan spiritual emosional freedom technique ( SEFT) . Selain murah, teknik ini tidak memiliki dampak negatif pada tubuh karena merupakan teknik pengendalian rasa sakit non-farmakologis. Sebagai konsep solusi untuk mengatasi masalah ini, ada kebutuhan untuk meningkatkan informasi dan implementasi petugas kesehatan untuk pasien kanker servik tentang metode untuk mengurangi nyeri. Salah satu manajemen nyeri kanker servik adalah dengan teknik penggabungan antara latihan nafas dalam dan spiritual emosional freedom technique (Frilasari, 2020).

\section{METODE}

Penerapan terapi relaksasi pernafasan dan spiritual emosional freedom technique ( SEFT) dilakukan 1 kali setiap pertemuan dengan kisaran waktu 15 menit selama 3 hari dengan di awali dengan penerapan relaksasi pernafasan yang bertujuan untuk merilekskan pasien pertemuan tidak terstruktur mengikuti pola pada responden. Sempel pada penerapan ini yaitu pasien kanker servik stadium IIIB. Metode yang digunakan menggunakan metode studi kasus yang dilaksanakan di ruang Rajawali 4B RSUP Dr. Kariadi. Responden yang digunakan yaitu pasien dengan diagnosa medis kanker servik stadium IIIB yang mengalami nyeri. Peralatana yang dibutuhkan pada penerapan ini yaitu lembar pengkajian dan lembar pengkajian nyeri menggunakan Numeric reting scale. Pengukuran skala nyeri dilakukan sebelum dilakukannya pemberian terapi relaksasi pernafasan dan penerapan SEFT pada pasien dan sesudah dilakukan terapi SEFT.

\section{HASIL}

Hasil studi menunjukkan bahwa pasien kanker servik di RSUP Dr. Kariadi diruang Rajawali 4B Semarang yang berjumlah 2 responden. Keduanya berjenis kelamin perempuan dan memiliki kesamaan dalam 
Amalia Warnandiah Safitri - Penurunan Nyeri dengan Intervensi Kombinasi Terapi Relaksasi Pernafasan dan Terapi SEFT pada Pasien dengan Kanker Servik Stadium IIIB

usia yaitu 54 tahun dan memiliki diagnosa kanker servik stadium IIIB, pada saat pengkajian pada keduanya ditemukan nyeri saat dilakukan pengkajian nyeri dengan Numeric reting scale. pada pasien pertama diketahui hasil skala nyeri 4 dan pasien kedua dengan skala nyeri 3 lalu dilakukan perencanaan pemberian terapi nonfarmakologis kepada kedua pasien yaitu terapi relaksasi pernafasan dan terapi seft setelah diajarkan terapi relaksasi pernafasan dan terapi seft dengan durasi waktu kurang lebih 15 menit menunjukkan hasil yang sama pada hari pertama, sampai hari ketiga dilakukan kembali terapi relaksasi pernafasan dan terapi seft dengan durasi waktu 15 menit, setelah di lakukan pengkajian skala nyeri pada pasien pertama dihari pertama yaitu 4 dan skala nyeri pada pasien kedua dihari pertama pada skala 3 dan setelah diberikan tindakan kedua pasien merasa lebih tenang. Pasien pertama mengalami kemajuan di hari ke dua dengan adanya penurunan skala nyeri menjadi 3 dan untuk pasien kedua masih berada pada skala 3. Evaluasi akhirr dihari ke tiga pasien pertama berada pada skala nyeri 3 dan untuk pasien kedua mengalami penurunan di skala 2. Batasan karakteristik nyeri dari kedua pasien yaitu laporan secara verbal atau non verbal, gerakan melindungi dan tingkah laku berhati-hati. Kesimpulan ada penurunan skala nyeri terhadap pasien kanker servik setelah diajarkan terapi nonfarmakologi relaksasi pernafasan dan terapi seft.

Tabel 1

Skala nyeri responden sebelum dan sesudah terapi $(\mathrm{n}=3)$

\begin{tabular}{ccccc}
\hline No & Responden & Hari 1 & Hari 2 & Hari 3 \\
\hline 1. & P1 & $\begin{array}{c}4 \\
\text { (Nyeri } \\
\text { sedang) }\end{array}$ & $\begin{array}{c}3 \\
\text { (Nyeri } \\
\text { ringan) }\end{array}$ & $\begin{array}{c}3 \\
\text { (Nyeri } \\
\text { ringan) }\end{array}$ \\
\hline 2. & P2 & $\begin{array}{c}3 \\
\text { (Nyeri }\end{array}$ & $\begin{array}{c}3 \\
\text { (Nyeri }\end{array}$ & $\begin{array}{c}\text { (Nyeri } \\
\text { ringan) }\end{array}$ \\
& & & & ringan) \\
\hline
\end{tabular}

\section{PEMBAHASAN}

Penelitian tentang pengaruh relaksasi nafas dalam dan terapi SEFT terhadap nyeri pada pasien kanker servik ini dilaksanakan di RSUP dr.Kariadi Semarang. Adapun ruangan yang digunakan untuk tempat penelitian adalah Ruang Rawat Inap Rajawali 4B. Hasil studi kasus ini menunjukkan bahwa relaksasi nafas dalam dan terapi SEFT mampu menurunkan skala nyeri pada pasien kanker servik. Pada kasus kali ini peneliti menggunakan dua sempel pasien penderita kanker servik dengan stadium IIIB dan usia yang sama. Pada penelitian ini, Pasien sebelumnya tidak pernah mengetahui apa itu terapi relaksasi nafas dalan dan SEFT, namun setelah diberikan penyuluhan tentang terapi relaksasi nafas dalam dan SEFT pasien mampu memiliki pengetahun yang cukup baik. Sistem kerja Spiritual Emosional Freedom Technique (SEFT) mempunyai prinsip hamper sama dengan akupresur. Teknik terapi SEFT memiliki tiga tahap yang berusaha merangsang titik- titk kunci 12 jalur energi (energi meridian) dalam tubuh yang sangat besar pengaruhnya terhadap tubuh kita (Puspita, 2018).

Menurut National Safety Council relaksasi pernafasan dalam adalah relaksasi dengan menggunakan nafas yang pelan dan dalam, teknik relaksasi nafas dalam merupakan suatu bentuk asuhan keperawatan, yang dalam hal ini perawat mengajarkan kepada pasien bagaimana cara melakukan nafas dalam, nafas lambat (menahan inspirasi secara maksimal) dan bagaimana menghembuskan nafas secara perlahan. Tujuan relaksasi pernafasan adalah untuk meningkatkan ventilasi alveoli, memelihara pertukaran gas, mencegah atelektasi paru, merilekskan tegangan otot, meningkatkan efisiensi batuk, mengurangi stress baik stress fisik emosional yaitu menurunkan intensitas nyeri (mengontrol atau mengurangi nyeri) dan menurunkan kecemasan. Salah satu manajemen non farmakologis untuk mengurangi nyeri dan 
Amalia Warnandiah Safitri - Penurunan Nyeri dengan Intervensi Kombinasi Terapi Relaksasi Pernafasan dan Terapi SEFT pada Pasien dengan Kanker Servik Stadium IIIB

merilekskan pasien yaitu dilakukan dengan relaksasi nafas dalam. Relaksasi nafas dalam merupakan suatu bentuk asuhan keperawatan, yang dalam hal ini perawat mengajarkan kepada pasien bagaimana cara melakukan nafas dalam, nafas lambat (menahan inspirasi secara maksimal) dan bagaimana menghembuskan nafas secara perlahan, selain itu juga dapat menurunkan kecemasan dan mengurangi ketidaknyamanan atau nyeri, teknik relaksasi nafas dalam juga dapat meningkatkan ventilasi paru dan meningkatkan oksigenasi darah.

Salah satu manajemen non farmakologis untuk mengurangi nyeri yaitu dilakukan dengan relaksasi nafas dalam. Relaksasi nafas dalam merupakan suatu bentuk asuhan keperawatan, yang dalam hal ini perawat mengajarkan kepada pasien bagaimana cara melakukan nafas dalam, nafas lambat (menahan inspirasi secara maksimal) dan bagaimana menghembuskan nafas secara perlahan, selain itu juga dapat merilekskan pasien, menurunkan kecemasan dan mengurangi ketidaknyamanan atau nyeri, teknik relaksasi nafas dalam juga dapat meningkatkan ventilasi paru dan meningkatkan oksigenasi darah (Frilasari Heni, 2020)

Terapi relaksasi pernafasan merupakan teknik untuk mengurangi sensasi nyeri dengan cara merelaksasikan otot (Gasshani, 2016). Manajemen nyeri non farmakologis biasa digunakan untuk mengatasi nyeri tingkat ringan dan sedang. Manajemen ini digunakan karena menejemen non farmakologi ini tidak menimbulkan efek samping tidak seperti obat - obatan, karena terapi ini menggunakan cara dengan proses fisiologi. Adanya penurunan skala nyeri pada pasien setelah diberikan terapi Spiritual Emotional Freedom Technique (SEFT) (Puspita, 2018).

Pelaksanaan terapi SEFT ini dibagi menjadi 3 langkah yaitu yang pertama adalah

langkah Set- up sambil menekan bagian dada atas atau titik sore spot atau bagian karate chop dengan mengucapkan kalimat The Set - Up ataupun doa yang khusyu seta dibarengi dengan rasa ikhlas dan pasrah yang di tujukan untuk Yang Maha Kuasa."The Set-Up" bertujuan untuk memastikan agar aliran energi tubuh kita terarahkan dengan tepat. Langkah ini dilakukan untuk menetralisir "Psychological Reversal" atau perlawanan psikologis (biasanya berupa pikiran negatif spontan atau keyakinan bawah sadar negative), aplikasi meditasi dan reframing. Kesalahan atau kurang spesifiknya kalimat set-up bisa mengakibatkan SEFT kurang efektif, bahkan dalam beberapa kasus efeknya malah kebalikan dari yang diinginkan.

Tahapan kedua adalah Tune In yakni dengan merasakan rasa sakit (nyeri) yang kita alami, kemudian pikiran kita mengarahkan ke tempat sakit yang dirasakan. Bukan kita tolak rasa sakit tersebut namun kita terima kondisi tersebut. Tahap ini merupakan bagian dari self Hypnotherapy untuk menghapus alam bawah sadar kita yang menjadi penyebab energi negatif yang dialami. Dalam dosis ringan ringan disebut dengan affirmasi.

Tahap terakhir adalah tapping dengan mengetuk ringan pada 18 titik bagian tubuh dengan menggunakan dua jari sebanyak 5 kali ketuak di setiap titiknya. Pada tahapan ini bagian yang diketuk ringan diketuk beberapa kali akan berdampak ternetralisirnya gangguan emosi atau rasa sakit yang dirasakan, karena aliran energi tubuh berjalan dengan normal dan seimbang kembali. Dengan melakukan teknik ini subyek akan terlatih bersikap rileks secara mendalam ketika menghadapi situasi yang membuat subyek marah dan mereduksi ketegangannya. Proses ini sering digambarkan sebagai keterampilan coping aktif untuk mengontrol kecemasan dan kegelisahan klien. Meskipun dalam sekali 
Amalia Warnandiah Safitri - Penurunan Nyeri dengan Intervensi Kombinasi Terapi Relaksasi Pernafasan dan Terapi SEFT pada Pasien dengan Kanker Servik Stadium IIIB

pelaksanaan dilakukan tapping di 18 titik (Budianto, 2016)

Penelitian ini sejalan dengan penelitian yang sudah pernah dilakukan oleh (Brahmantia,2018) yaitu tentang penelitian terapi SEFT yang biammenurunkan nyeri pada pasien kankerstadium II, nyeri yang cukup hebat pada penderita kanker. Setelah diberikan terapi SEFT ternyataintensitas nyeri menurun, bahkan ada bevberapa pasien yang menyatakan bahwa nyeri hilang. Tapping pada tubuh manusia ini sudah dijelaskan secara ilmiah bahwa titik meridian tubuh bisa mampu mengaktifkan system energy tubuh pada manusia sehingga dapat menurunkan serta menyembuhkan nyeri yang dirasakan pada pasien.

Pengobatan non farmakologi ini adalah terapi pelengkap yang bisa mengurangi serta mengontrol nyeri, intervensi ini biasa digunakan untuk pengobatan fisik maupun perilaku kognitif. Terapi spiritual emotional freedom technique (SEFT) merupakan terapi yang biasa digunakan untuk mengurangi intensitas nyeri pada penderita kanker. Teknik yang digunakan pada terapi SEFT yaitu teknik penggabungan dari sisteem tubuh (energy medicine) dan terapi spiritual yang disertai penggunaan tapping pada titik titik tertentu dalam tubuh (Gasshani, 2016)

Penggunaan titik jalur energy meridian pada penderita kanker bisa dijelaskan dengan neuro- fisiologi dari system meridian akupuntur analgesia. Penelitian ini sejalan dengan Kober yang meneliti adanya pengurangan nyeri pada kasus luka. Penelitian yang di lakukan Craig dalam artikelnya yang berjudul cancer pain treatment melakukan EFT pada pasien kanker payudara yang menunjukan adanya penurunan skala nyeri. Teori gate control yang merangsang titik di jalur meridian adalah rangsangan yang dilanjutkan ke serabut saraf A- Beta yang diameternya besar (yang bisa menghantarkan impuls lebih cepat) yang menuju ke saraf spinal atau kranial menuju ke kornu posterior medulla spinalis. Di dalam medulla spinaslis terdapat substantia gelatinosa yang ditugaskan bekerja sebagai "gate control", yang bertugas merangsang dan mengatur sebelum diteruskan ke serabut saraf aferen ke sel- sel transmisi. Tujuannya untuk mempengaruhi dan menutupi "gate control",serabut saraf cepat A- Beta yang mempunyai tugas merangsang dan meneruskan haruus mempunyai frekuensi yang tinggi dan intensutas yang rendah. Rangsangan nyeri yang sudah dihantarkan oleh serabut ini danat tertahan dan tidak langsung diteruskan ke sel - sel transmisi, sehingga tidak dapat diteruskan ke pusat nyeri (Hakam, 2010)

Studi kasus yang peneliti kerjakan mencakup 2 pasien dengan diagnose medis kanker servik yang kebetulan kedua responden yang peneliti gunakan mempunyai kesamaan didalam usia yaitu pasien dengan kanker servik stadium IIIB dengan usia 54 tahun dengan usia perkawinan yang cukup muda diantara keduanya, untuk pasien pertama menikah pada usia 14 dan untuk pasien ke dua berusia 15 tahun.Usia 54 tahun bisa meningkatkan resiko kanker servik yang dikarenakan adanya penggabungan peningkatan dan pertambahan lama waktu terjadinya pemaparan terhadap karsinogen dan adanya faktor kelemahan sistem kekebalan tubuh akibat usia. Faktor pernikahan dini juga bisa di jadikan faktor predisposisi pada pasien kanker servik. Yang sejalan dengan penelitian Aziyah yang menjelaskan bahwa adanya hubungan antara umur pertama kali melakukan hubungan seks dengan kejadian kanker servik yang dikaitan dengan sel - sel mukosa epitel yang baru matang pada usia wanita 20 tahun, sehingga apabila melakukan hubungan seks sebelum usia 20 tahun sel mukosa rawan terhadap rangsangan dari luar yang merupakan zatzat kimia yang termasuk ada dalam sperma (Aziyah, 2017). 
Amalia Warnandiah Safitri - Penurunan Nyeri dengan Intervensi Kombinasi Terapi Relaksasi Pernafasan dan Terapi SEFT pada Pasien dengan Kanker Servik Stadium IIIB

Kedua responden yang peneliti ambil memiliki faktor pendukung terhadap nyeri yang berbeda, untuk responden yang pertama pasien belum pernah memiliki pengalaman nyeri sama sekali dan baru merasakan nyeri pada sakit sekarang ini. Responden yang pertama ini juga memiliki faktor pendukung yang kuat terhadap penurunan nyerinya seperti adanya dukungan suami, anak dan saudara yang setia menunggu kesembuhan pada responden. Responden yang kedua sudah memiliki pengalaman nyeri yaitu responden kedua ini lebih dahulu mengalami sakit kanker servik dan juga sudah pernah melakukan terapi sinar selama satu kali. Faktor pendukung untuk responden kedua terhadap nyeri kurang baik pasien sudah tidak memiliki suami dan hanya satu orang anak yang menunggu sehingga pasien kurang dukungan untuk kesembuhannya terutama saat mengalami nyeri pasien kurang mendapatkan dukungan untuk mengurangi rasa nyerinya.

Penelitian ini sejalan mendukung seperti penelitian yang dilakukan oleh susanti dengan penelitiannya tentang pengurangan skala nyeri pada penderita luka dengan cara meridian akupresure yang hampir sama dengan terapi SEFT, sama juga dengan penelitian yang dilakukan oleh Hui untuk kasus mengetahui penurunan skala nyeri dan rasa takut yang dilakukan dengan akupuntur. Sejalan juga dengan penelitian yang dilakukan oleh Craig 2016 tentang penurunan skala nyeri pada penderita kanker payudara yang menggunakan terapi EFT, dengan hasil menunjukan bahwa adanya penurunan nyeri dan tidak terjadinya kekambuhan rasa nyeri dalam waktu 4 bulan (Susanti, 2017)

Mekanisme dari tapping ini sendiri dilakukan pada satu titik system meridian yang dapat berperan pada endorphin yang merupakan substansi atau neurotransmiter yang menyerupai morfin yang bisa dihasilkan oleh tubuh secara alami yang dapat dikeluarkan oleh periaqueductal grey matter. Penurunan skala nyeri ini dihasilkan karena adanya keberadaan endorphin pada sinaps sel-sel saraf. Menghilangkan nyeri bisa dilakukan dengan penggosokan atau pemijatan dibagian tubuh yang mengalami sakit hal ini sesuai dengan teori pengendalian gerbang (gate control). Sistem kerjanya yaitu apabila digosok atau dipijat maka aktivasi seratserat besar bisa dirangsang, sehingga yang terjadi gerbang untuk aktifitas serat yang berdiameter kecil ( nyeri ) bisa tertutup. Salah satu contoh dari aplikasi ini yaitu pemakaian stimulasi saraf dengan listrik transkutis ataupun pemijatan (Hakam, 2010)

Kelemahan pada studi kasus ini adalah terkendalanya ruangan saat di lakukan terapi yaitu situasi yang kurang sedikit mendukung karena ramainya penunggu pasien yang mengakibatkan kurang efektifnya tindakan yang dilakukan. Pasien jadi kurang konsentrasi saat melakukan terapi. Seharusnya pasien diberikan terapi kombinasi relaksasi pernafasn dan terapi SEFT dengan kondisi lingkungan yang cukup tenang dan bisa merasakan dengan khusyuk terapi ini, sehingga kombinasi relaksasi pernafasn dan terapi SEFT bisa efektif untuk mengurangi rasa nyeri yang dirasakan pasien .

\section{SIMPULAN}

Adanya penurunan intensitas nyeri pada penderita kanker servik stadium IIIB yang sudah diberikan intervensi dengan teknik relaksasi nafas dalam dan terapi SEFT memiliki penurunan yang cukup baik. Hal ini bisa disimpulkan bahwasannya pemberian terapi SEFT bisa efektif dalam menangani kasus nyeri yang dialami oleh pasien kanker servik stadium IIIB. Dengan adanya studi kasus ini terapi SEFT bisa digunakan untuk pelayanan keperawatan untuk membantu mengurangi intensitas nyeri pada pasien kanker servik stadium IIIB, sehingga keluarga serta pasien 
Amalia Warnandiah Safitri - Penurunan Nyeri dengan Intervensi Kombinasi Terapi Relaksasi Pernafasan dan Terapi SEFT pada Pasien dengan Kanker Servik Stadium IIIB

mendapatkan pengetahuan tentang penanganan nyeri dengan non farmakologi.

\section{UCAPAN TERIMA KASIH}

Puji syukur kepada Allah SWT atas segala rahmat dan karunia-Nya, sehingga peneliti dapat menyelesaikan Karya Ilmiah Akhir Ners. Terima kasih kepada Direktur RSUP Dr. Kariadi Semarang yang telah mengizinkan kami praktek sehingga kami dapat menyelesaikan studi kasus tersebut yang kedua terima kasih kepada responden beserta keluarga yang telah mengizinkan saya untuk mengelola sebagai kasus yang ketiga terima kasih kepada pembimbing karena telah membimbing saya dan temanteman bisa sampai sejauh ini semoga hasil studi kasus ini dapat dijadikan sebagai bahan masukan dan memberikan informasi tentang Pengaruh Penurunan Nyeri Dengan Intervensi Kombinasi Terapi Relaksasi Pernafasan Dan Terapi SEFT Pada Pasien Dengan Kanker Servik.

\section{REFERENSI}

Aziyah, A., Sumarni, S., \& Ngadiyono, N. (2017). Faktor Resiko Yang Berhubungan Dengan Kejadian Kanker Servik; Studi Kasus Di Rsup Dr. Kariadi Semarang. Jurnal Riset Kesehatan, $6(1)$

20. https://doi.org/10.31983/jrk.v6i1.2085

Brahmantia, B., Program, T. H., \& Keperawatan, S. M. (2018). Pengaruh Spiritual Emotional Freedom Technique (SEFT) Terhadap Penurunan Nyeri Dan Kecemasan Pada Pasien Pasca Bedah Transurethiral Resection Prostate (TURP) Di RSUD dr. Soekardjo Kota Tasikmalaya. Jurnal Kesehatan Karya Husada, 6(2), 18.

Dan, R., \& Payudara, K. (2018). Analisis Peran Puskesmas Kedungmundu Kota Semarang Dalam Melaksanakan Program Deteksi Dini Kanker Leher Rahim Dan Kanker Payudara. Jurnal Kesehatan Masyarakat (e-Journal), 6(4),
$42-50$.

Frilasari Heni, H. T. (2020). Penerapan Teknik Relaksasi Progresif Terhadap Derajat Nyeri Persalinan Kala 1 Fase Aktif. Jurnal Keperawatan.

Gasshani. (2016). Pengaruh Terapi Relaksasi Pernafasan terhadap Penurunan Skala Nyeri.

Hakam, M., Yetti, K., \& Hariyati, R. T. S. (2010). Intervensi Spiritual Emotional Freedom Technique untuk Mengurangi Rasa Nyeri Pasien Kanker. Makara Journal of Health Research, 13(2), 91-95. https://doi.org/10.7454/msk.v13i2.375

Meihartati. (2017). Hubungan Faktor Predisposisi Ibu Terhadap Kanker Servik (Relationship of Medical Predisposition Factors To Servic Cancer). Jurnal Darul Azhar, 4(1), 8-13. Retrieved from https://studylibid.com/doc/1134006/hubung an-faktor-predisposisi-ibu-terhadap-kanker.

Natosba, J., Rahmania, E. N., \& Lestari, S. A. (2019). Studi Deskriptif : Pengaruh Progressive Muscle Relaxation Dan Hypnotherapy Terhadap Nyeri Dan Kecemasan Pasien Kanker Serviks Descriptive Study: the Effect of Progressive Muscle Relaxation and Hypnotherapy on Pain and Anxiety of Cervical Cancer Patients.

Puspita, (Erlin). (2018). Pengaruh Spiritual Emotional Freedom Technique (Seft) terhadap Penurunan Dismenore Primer pada Remaja Putri. Quality, 12(1), 14-19. https://doi.org/10.36082/qjk.v12i1.25

Rahmania, E. N., Natosba, J., Adhisty, K., Lintas, J., Zona, P. K., Abdul, F. G., \& Ilir, K. O. (n.d.). Pengaruh Progressive Muscle Relaxtation Terhadap Program Studi Ilmu Keperawatan Fakultas Kedokteran Universitas Sriwijaya Pendahuluan Kanker serviks merupakan kanker pada wanita yang menyerang bagian leher rahim yang disebabkan oleh virus Human Papilloma V.

Susanti, N. L. (2017). Dukungan Kelurga dalam Meningkatkan Kualitas Hidup Kanker Serviks. Jurnal Ners Lentera, 5(2), 106-115. Retrieved from https://www.researchgate.net/publication/3 37462419_Dukungan Keluarga Dengan Kualitas Hidup Pasien Ca Servik 